\title{
Prirojene presnovne bolezni in diagnosticiranje spektroavtističnih motenj
}

\section{Inborn Errors of Metabolism and Metabolic Work-up in Autism Spectrum Disorders}

Anja Krivec Penič, Živa Prijatelj, Manca Ločičnik, Mojca Žerjav Tanšek

\section{Izvleček}

Spektroavtistične motnje (SAM) so kompleksne razvojne motnje, ki se kažejo predvsem kot kakovostno spremenjeno vedenje na področju socialnih interakcij, besedne in nebesedne komunikacije ter imaginacije. Pogostost SAM se v zadnjih letih izrazito povečuje. Vzroka še niso opredelili, najverjetnejši etiološki vzrok pa je interakcija med genetskimi dejavniki in okoljskimi vplivi. Med genetske vzroke za avtizem sodijo tudi prirojene presnovne bolezni (PPB), ki so dokazane pri 2-5\% otrok s SAM. Na PPB kot vzrok za spektroavtistično motnjo pomislimo predvsem ob anamnestičnem podatku o regresiji v razvoju in pridruženih dodatnih kliničnih znakih. Diagnostična potrditev zahteva individualno obravnavo in usmerjene presnovne in genetske preiskave. V prihodnosti bodo pri diagnosticiranju SAM v ospredju genetske analize, usmerjene predvsem v potrditev monogenskih vzrokov SAM, med katere uvrščamo tudi PPB. Cilj bo čimprejšnje diagnosticiranje, morda že prenatalno, zlasti če bo z razvojem zdravil dostopno vzročno gensko zdravljenje. $\checkmark$ preglednem prispevku povzemamo priporočila za diagnosticiranje prirojenih presnovnih bolezni pri bolnikih s sindromskim avtizmom in s prikazom primera otroka $z$ lizosomsko boleznijo kopičenja in SAM opozarjamo na pomen pravočasne in pravilno postavljene diagnoze.

Ključne besede: spektroavtistične motnje, sindromski avtizem, nesindromski avtizem, prirojene presnovne bolezni, diagnosticiranje. 


\section{Uvod - značilnosti spektroavtistične motnje}

Spektroavtistične motnje (SAM) so kompleksne razvojne motnje, ki se kažejo predvsem s kakovostno spremenjenim vedenjem na področju socialne interakcije, besedne in nebesedne komunikacije ter imaginacije (1). Značilni so omejeni in ponavljajoči se vzorci obnašanja, zanimanja in aktivnosti (2). Simptomi se tipično začnejo pred 36. mesecem starosti, končno diagnozo SAM pa navadno postavimo med 3. in 5. letom starosti (3). Značilno je, da težave z leti postopno napredujejo (4).

Izraz nesindromski (tudi enostaven/idiopatski/esencialni) avtizem se nanaša na posameznike s SAM, ki nimajo dismorfnih značilnosti oz. drugih znakov ter malformacij ali znanih nevroloških bolezni (5). Izraz sindromski (tudi kompleksen/neesencialni) avtizem pa opisuje otroke, ki imajo SAM in dodatne klinične najdbe ali bolezni in so pogosto del klinično potrjenih ali molekularno potrjenih sindromskih stanj. Bolniki s SAM imajo v 5-10 \% monogenske sindrome s pogosto pridruženimi dodatnimi bolezenskimi simptomi, kot so refraktarna epilepsija, težke gibalne motnje, druga napredujoča nevrološka stanja in dismorfne značilnosti. Najpogosteje je sindromski avtizem del znanih genetskih stanj, kot so Rettov sindrom, tuberozna skleroza, sindrom fragilnega X, Prader-Willijev sindrom, Angelmanov sindrom in drugi $(2,3)$.

Vzroka SAM še niso opredelili, a jih $\mathrm{v}$ raziskavah povezujejo $\mathrm{z}$ različnimi kromosomskimi nepravilnostmi, kompleksnimi genskimi različicami in epigenetiko, pri čemer povezava med genotipom in fenotipom ni pojasnjena $(2,6)$. Geni, ki jih povezujejo s SAM, so udeleženi pri nastanku sinaps, regulaciji genske transkripcije in remodelaciji kromatina (7). Ti procesi so zelo pomembni med embrionalnim razvojem možganov (8). Opazimo lahko izrazito prekrivanje genov $s$ tveganjem za razvoj SAM in genov s tveganjem za razvoj shizofrenije, depresije in motenj pozornosti s hiperaktivnostjo (ADHD) (7). Po dosedanjih ocenah naj bi k nagnjenosti k razvoju SAM prispevalo 200-1000 različnih genov (9). Izsledki najnovejših raziskav kažejo, da dednost k nastanku prispeva kar $80 \%$, torej več, kot je bilo sprva ocenjeno (10). Hkrati z razpoložljivimi genetskimi analizami v več kot $80 \%$ primerov neposrednega genskega vzročnega dejavnika ne moremo natančneje opredeliti (6). Prispevek pogostih podedovanih genskih variant k etiologiji avtizma ocenjujejo na $15-50 \%$ (11-13). Sprožilec SAM je najverjetneje interakcija med genetskimi dejavniki in okoljskimi vplivi $(2,4)$. Z genetskimi vzroki za SAM se ukvarjajo v najnovejših raziskavah $(7,8,14)$. Genske variante s tveganjem za razvoj SAM so lahko podedovane ali nastanejo kot nove genetske spremembe. Prav pri slednjih je tveganje SAM dodatno večje (14).

Med genetske vzroke za avtizem uvrščamo tudi prirojene presnovne bolezni (PPB), ki so dokazane pri 2-5\% otrok s SAM (15). Avtizem je lahko del klinične slike ali celo edina manifestacija PPB (6). Redko je prvi znak PPB (npr. pri nezdravljeni fenilketonuriji, klasični homocistinuriji, Sanfilippovi bolezni, pomanjkanju encima ornitin transkarbamilaza) (16). V teh primerih je za ugodno napoved izida bolezni ključno čim prejšnje diagnosticiranje PPB (16). V številnih raziskavah so iskali povezavo med razvojem SAM in okoljem ter izpostavili možne vplive dejavnikov, kot so okoljski toksini, motnje v uravnavanju imunskega sistema, črevesna disbioza, perinatalni stres pa tudi spremenjene koncentracije mikroelementov $\mathrm{v}$ krvni plazmi, kot so cink, baker, živo srebro ali svinec $(4,6,17-25)$. Dosedanje raziskave neposredne povezanosti med težkimi kovinami in nastankom SAM niso pokazale (23). $V$ najnovejših ameriških priporočilih povzemajo, da dokazov glede koristnosti rutinskega določanja okoljskih toksinov ali težkih kovin v laseh, krvi ali urinu pri otrocih s SAM ni (3).

Otroci s SAM imajo pogosteje pridružene gastrointestinalne motnje (26), epilepsijo (27), motnje pozornosti (28), anksioznost (29) in alergije (30). Epilepsijo ima 5-38\% posameznikov s SAM, za razliko od splošne populacije, kjer je razširjenost epilepsije 1-2 \% (31-35). Epilepsija je pogosto del klinične slike pri bolnikih s SAM, ki imajo pridružene tudi PPB, kot so nepravilnosti v mitohondrijski presnovi (36) ter presnovi folatov $(37,38)$, holesterola (39) in razvejanih aminokislin (40).

Diagnoza SAM je kompleksen klinični proces, ki temelji na diagnostičnih merilih, opredeljenih v DSM-V (Diagnostični in statistični priročnik za duševne motnje) in v MKB-10 (Mednarodna klasifikacija bolezni 10$)(1,6)$. Pravilno diagnosticiranje SAM temelji na natančni anamnezi s poudarkom na vedenjski, govorni, socialni in kognitivni oceni. V DSM-V so simptomi SAM razdeljeni v dve skupini, ki sta socialna komunikacija (prepoznava in vstopanje v komunikacijo, verbalno in neverbalno razumevanje komunikacije) in socialne interakcije $z$ omejenimi in ponavljajočimi se vedenjskimi vzorci (stereotipija, rutinsko vedenje, preokupacija in senzorna hiporeaktivnost ali hiperreaktivnost). Za diagnostično potrditev SAM naj bi bila izpolnjena vsa tri merila socialnega odstopanja v komunikaciji in dodatno dve značilnosti od štirih $v$ domeni socialne interakcije (41). Diagnosticiranje izvajajo usposobljeni strokovnjaki s posebnimi diagnostičnimi orodji, pri diagnosticiranju pa je lahko v pomoč tudi vprašalnik, ki ga izpolnijo otrokovi starši, pogosteje pa strokovnjak s starši opravi diagnostični intervju. Pomembni so predvsem testi vedenja in komunikacije, na primer Childhood Autism Rating Scale (CARS, druga izdaja) in Autism Diagnostic Observation Schedule (ADOS, druga izdaja) $(42,43)$. $V$ diagnostičnem procesu moramo opredeliti tudi morebitno organsko etiologijo SAM in izključiti bolezni, ki jih lahko zdravimo. Zgodnje diagnosticiranje in specializirana obravnava otrok s SAM izboljšata klinični izid, a sta najbolj učinkovita zgodaj v življenju (44). Biomarkerjev, ki bi omogočili bolj točno 
in zgodnje diagnosticiranje avtizma, zaenkrat še ne poznamo $(1,45)$.

Število otrok in mladostnikov, ki imajo SAM, se v zadnjih letih izrazito povečuje. $V$ slovenskih smernicah za celostno obravnavo otrok s SAM iz leta 2009 opisujejo, da je razširjenost (prevalenca) SAM v razvitem delu Evrope in ZDA $6 / 1000$ (1). V novejši literaturi navajajo precej višje številke; tako Glinton s sodelavci v preglednem prispevku iz leta 2019 navaja razširjenost (prevalenco) SAM pri ameriških otrocih, starejših od 8 let, 16,8/1000 otrok oz. 1 primer na 59 otrok $(46,47)$. Aktualni podatki kažejo, da se razširjenost avtizma v posameznih državah razlikuje in je najvišja v Aziji (Hong Kong 37.2/1000 otrok) (48). V Evropi naj bi imel SAM eden na 89 otrok (49). Vloga rasnih in etičnih dejavnikov v etiologiji SAM je za zdaj slabo opredeljena (7). V preteklosti so $v$ raziskavah skušali opredeliti povezavo med pogostejšim pojavljanjem avtizma pri otrocih višjega socialno-ekonomskega statusa, a v kasnejših epidemioloških raziskavah povezave med pojavljanjem avtizma in višjim socialno-ekonomskim statusom niso potrdili (49). V ZDA poročajo o nižji razširjenosti avtizma pri otrocih $z$ afroameriškim in latinskoameriškim poreklom, kar je najverjetneje posledica manj intenzivnega diagnosticiranja SAM v teh etničnih skupinah $(3,50)$.

Večja razširjenost avtizma je vsaj delno posledica napredka v diagnostičnih metodah in $v$ enotnih diagnostičnih smernicah, pa tudi večje dostopnosti do strokovnjakov, večjega javnega zavedanja in bolj zgodnjega diagnosticiranja (4). Štirikrat pogosteje so prizadeti moški, a genetskega mehanizma omenjene razlike med spoloma še vedno ne poznamo (51).

\section{Prirojene presnovne bolezni s klinično sliko spektroavtističnih motenj}

V skupini otrok z avtizmom so PPB prisotne v manj kot $5 \%$ (6). Prirojene presnovne bolezni s pridruženim fenotipom SAM ali celo s SAM kot vodilnim kliničnim simptomom so nezdravljena fenilketonurija, sindromi z motnjo presnove kreatina, pomanjkanje biotinidaze, motnje $v$ presnovi purinov in pirimidinov, motnje $v$ biosintezi holesterola (Smith-Lemli-Opitzov sindrom), motnje v ciklu sečnine, mukopolisaharidoza tipa III (Sanfilippov sindrom), infantilna ceroidna lipofuscinoza in pomanjkanje sukcinat-semialdehidne dehidrogenaze (6) (Tabela 1). Tudi mitohondrijske bolezni se lahko kažejo s klinično sliko SAM (16). Pri sumu na PPB kot vzroku SAM je pomemben klinični anamnestični podatek o regresiji v razvoju, ko otrok preneha napredovati in izgublja že usvojene razvojne mejnike (8). Podatek ni specifičen za SAM pri PPB, saj po raziskavah pri skoraj četrtini otrok s SAM v starosti med 18. in 24. mesecem opisujejo regresijo jezikovnih in socialnih veščin (52).

Kdaj pomislimo na PPB pri otroku ali mladostniku s SAM?

Pri otroku z izoliranim nesindromskim SAM je verjetnost PPB majhna, zato naj bo testiranje na PPB usmerjeno ter vključuje natančno klinično oceno in oceno prisotnosti regresije $v$ razvoju ali sum na katero od PPB, ki jih povezujemo z razvojem SAM (3).

Fenilketonurija (PKU) je posledica povišane koncentracije fenilalanina $v$ serumu in je del osnovnih presejalnih testov pri novorojenčkih. Fenilalanin deluje nevrotoksično in vodi v strukturne možganske poškodbe ter motnje mišljenja in obnašanja (4). Pred uvedbo presejalnega presnovnega testiranja za novorojenčke so pri $21 \%$ otrok z avtizmom kasneje dokazali nezdravljeno PKU (53). V državah z uvedenim univerzalnim presejanjem, kjer simptomatske PKU skorajda ni, diagnostična merila za avtizem izpolnjuje 0,7 \% otrok s PKU, kar je še vedno več kot pri zdravih kontrolah (54).

Primarne motnje v delovanju mitohondrijev so prisotne pri $5 \%$ otrok s SAM in
PPB $(55,56)$. Ali mitohondrijska disfunkcija dejansko prispeva k patogenezi SAM ali je zgolj sopojav ob SAM, zaenkrat še ni natančno opredeljeno (56).

Mukopolisaharidoza tipa III (MPS tipa III) oz. Sanfilippov sindrom sodi med lizosomske bolezni kopičenja, ki so posledica pomanjkanja enega od lizosomskih encimov, vpletenih v razgradnjo glikozaminoglikanov, ki so del proteoglikanov zunajceličnega matriksa. Ta privede do prekomerne akumulacije glikozaminoglikanov v lizosomih, kar vodi v celične poškodbe in večsistemsko bolezen. Prizadeti so lahko vsi organski sistemi, najpogosteje živčni sistem, oči in vezivno tkivo. Poznamo štiri različne oblike bolezni MPS tipa III, ki jih označujemo s črkami A-D. Klinična slika je pri vseh tipih podobna (57). MPS tipa A je najpogostejša (58) in ima najtežji klinični potek (57). Zanjo je značilno, da sta prenatalni in zgodnji postnatalni razvoj navadno brez posebnosti (59). Za začetno fazo bolezni v prvih letih življenja so značilni zapoznel kognitivni razvoj, zaostanek v razvoju govora in vedenjske težave $(57,60,61)$. Med 3 . in 5 . letom starosti se vedenjske težave stopnjujejo; značilne so hiperaktivnost z elementi agresivnosti in motnje spanja $(59,62-64)$. V tem obdobju in kasneje bolniki ves čas napredujoče izgubljajo kognitivne sposobnosti (npr. govor, če so ga usvojili) in gibalne sposobnosti (motnje hoje, požiranja) $(57,60)$.

Otroci z MPS tipa IIIA in MPS tipa IIIB imajo lahko klinično sliko SAM $(61,65)$. Prvi znaki so zaostanek v govornem razvoju in motnje $v$ socialni komunikaciji $(66,67)$. Simptomi in diagnoza avtizma lahko zamaskirajo diagnozo MPS tipa III. To je tudi vzrok napačne ali pozne postavitve diagnoze osnovne bolezni MPS, kar pušča posledice predvsem v poznem genetskem svetovanju $(68,69)$. S prihajajočimi novimi genskimi zdravljenji bo zgodnja postavitev diagnoze še bolj pomembna. Zdravila za redno zdravljenje MPS tipa III zaenkrat še ni. Številne preiskave potekajo na področjih matičnih celic in genskega 


\begin{tabular}{|c|c|c|c|}
\hline PPB & Pričetek bolezni & Dodatni klinični znaki & Diagnostični testi \\
\hline $\begin{array}{l}\text { nezdravljena } \\
\text { fenilketonurija }\end{array}$ & neonatalno obdobje & $\begin{array}{l}\text { motnja v duševnem } \\
\text { razvoju, krči }\end{array}$ & $\begin{array}{l}\text { povišan fenilalanin v } \\
\mathrm{krvi}>1000 \mu \mathrm{mol} / \mathrm{l}\end{array}$ \\
\hline $\begin{array}{l}\text { motnje v presnovi } \\
\text { purinov in pirimidinov }\end{array}$ & prvo leto & $\begin{array}{l}\text { psihomotorični } \\
\text { zaostanek, epilepsija }\end{array}$ & $\begin{array}{l}\text { povišana ali znižana } \\
\text { sečna kislina v krvi in v } \\
\text { 24-urnem urinu, } \\
\text { purini in pirimidini v } \\
\text { urinu }\end{array}$ \\
\hline $\begin{array}{l}\text { bolezni v presnovi } \\
\text { kreatina }\end{array}$ & $3-24$ mesecev & $\begin{array}{l}\text { govorni zaostanek, } \\
\text { motnja v duševnem } \\
\text { razvoju, epilepsija }\end{array}$ & $\begin{array}{l}\text { spremenjeno } \\
\text { razmerje kreatin/ } \\
\text { kreatinin (in povišan } \\
\text { guanidinoacetat) } \\
\text { v urinu, znižan } \\
\text { vrh kreatina na } \\
\text { MR- spektroskopiji } \\
\text { možganov }\end{array}$ \\
\hline $\begin{array}{l}\text { pomanjkanje } \\
\text { biotinidaze }\end{array}$ & 3-12 mesecev & $\begin{array}{l}\text { ataksija, epilepsija, } \\
\text { kožni ekcem, razvojni } \\
\text { zaostanek }\end{array}$ & $\begin{array}{l}\text { aktivnost biotinidaze } \\
\text { v krvi }\end{array}$ \\
\hline $\begin{array}{l}\text { nevronalna ceroidna } \\
\text { lipofuscinoza (CLN) }\end{array}$ & $\geq 2$ leti & $\begin{array}{l}\text { razvojna gibalna } \\
\text { regresija in demenca, } \\
\text { spastičnost, epilepsija, } \\
\text { horeiformno gibanje, } \\
\text { izguba vida }\end{array}$ & $\begin{array}{l}\text { genetsko testiranje, } \\
\text { redkeje histopatološko } \\
\text { diagnosticiranje in } \\
\text { določanje encimske } \\
\text { aktivnosti }\end{array}$ \\
\hline $\begin{array}{l}\text { motnje v biosintezi } \\
\text { holesterola } \\
\text { (Smith-Lemli-Opitzov } \\
\text { sindrom) }\end{array}$ & v prvem letu življenja & $\begin{array}{l}\text { malformacije } \\
\text { (genitalne, sindaktilija } \\
\text { II in III na nogi), velik } \\
\text { razvojni zaostanek, } \\
\text { vedenjske motnjes } \\
\text { samopoškodovanjem }\end{array}$ & $\begin{array}{l}\text { nizek (ali normalen) } \\
\text { holesterol in visok } \\
\text { 7-dehidroholesterol v } \\
\text { plazmi }\end{array}$ \\
\hline motnje v ciklu sečnine & vse starosti & $\begin{array}{l}\text { epilepsija, vedenjski } \\
\text { problemi, bruhanje, } \\
\text { razvojni zaostanek }\end{array}$ & $\begin{array}{l}\text { hiperamoniemija } \\
\text { (amonijev ion }>100 \\
\mu \mathrm{mol} / \mathrm{l} \text { v krvi) }\end{array}$ \\
\hline Sanfilippov sindrom & po prvem letu & $\begin{array}{l}\text { motnja v duševnem } \\
\text { razvoju, hiperaktivnost, } \\
\text { regresija v razvoju }\end{array}$ & $\begin{array}{l}\text { analiza } \\
\text { glikozaminoglikanov } \\
\text { (MPS) v urinu }\end{array}$ \\
\hline $\begin{array}{l}\text { pomanjkanje sukcin- } \\
\text { semialdehidne } \\
\text { dehidrogenaze }\end{array}$ & $\geq 3$ mesece & $\begin{array}{l}\text { pomembna jezikovni in } \\
\text { kognitivni zaostanek, } \\
\text { epilepsija, vedenjski } \\
\text { izpadi }\end{array}$ & $\begin{array}{l}\text { akumulacija } \\
\text { 4-hidroksibutirata v } \\
\text { urinu/serumu/likvorju, } \\
\text { genetika }\end{array}$ \\
\hline $\begin{array}{l}\text { mitohondrijske } \\
\text { presnovne bolezni }\end{array}$ & v prvem letu življenja & $\begin{array}{l}\text { raznoliki znaki in } \\
\text { simptomi večorganske } \\
\text { prizadetosti }\end{array}$ & $\begin{array}{l}\text { mišična biopsija za } \\
\text { analizo aktivnosti } \\
\text { dihalne verige, genetika }\end{array}$ \\
\hline
\end{tabular}

TABELA 1. PRIROJENE PRESNOVNE BOLEZNI, KI SE NAJPOGOSTEJE KAŽEJO S KLINIČNO SLIKO SPEKTROAVTISTIČNE MOTNJE (PRIREJENO PO (6)).

TABLE 1. INBORN ERRORS OF METABOLISM THAT USUALLY PRESENT WITH THE CLINICAL PICTURE OF AUTISM SPECTRUM DISORDER (ADAPTED FROM (6)).

zdravljenja, bolnike pa že vključujejo tudi v klinične raziskave $(70,71)$.

$\checkmark$ prihodnosti bo $v$ diagnosticiranju SAM še bolj pomembna čim prejšnja izključitev morebitnih PPB, najbolje že prenatalno, če bo za monogenske vzroke SAM na voljo gensko zdravljenje. Veliko spremembo glede napovedi izida fenilketonurije je prineslo presejanje novorojenčkov, ki je omogočilo takojšnje ukrepanje in zdravljenje (5). PPB nimajo specifične klinične slike, čeprav ob določeni klinični sliki lahko pomislimo na specifično motnjo (5). Zaradi omenjenega je težko razviti specifičen diagnostični algoritem za sistematično klinično diagnosticiranje prirojenih presnovnih bolezni pri otrocih s SAM. Potrebna sta individualna obravnava vsakega posameznega bolnika in usmerjeno iskanje PPB.

Na PPB v povezavi s SAM pomislimo pri konsangvinosti, regresiji v razvoju, hudem govornem zaostanku, motnji v duševnem razvoju, refraktarni epilepsiji, ekstrapiramidnih znakih, blagih dismorfnih značilnostih, ataksiji, hipotoniji, izgubi vida/sluha, kroničnem kožnem izpuščaju, motnjah gibanja, mikrocefaliji/makrocefaliji, letargiji, cikličnem bruhanju in anomalijah možganov $(16,72)$. Večina PPB se pokaže $z$ jasnimi nevrološkimi znaki in drugimi manifestacijami, ki niso pogost del klinične slike SAM. Opisane klinične slike so del sindromskega avtizma in $v$ tej skupini bolnikov sta diagnosticiranje PPB in iskanje etiološkega vzroka strokovno utemeljeni $(3,6)$.

V številnih raziskavah so preučevali tudi smiselnost metabolnega presejanja pri otrocih z nesindromskim avtizmom, a ga avtorji ne priporočajo kot rutinski del diagnosticiranja $(5,6,45,47)$. Gougou s sodelavci predlaga, da bi otroci z avtizmom neznane etiologije opravili metabolno presejane za tiste PPB, ki imajo možnosti zdravljenja (organske acidurije, pomanjkanje biotinidaze, motnja presnove kreatina) (6). V primeru normalnih preiskav svetuje klinično sledenje, 
saj se znaki PPB lahko pojavijo v poteku bolezni (6). Razširjeno neonatalno presejanje v Sloveniji od bolezni, ki jih navajamo v Tabeli 1, vključuje le fenilketonurijo in kot sekundarni cilj lahko prepozna motnje v ciklu sečnine, medtem ko ostalih PPB, ki so prepoznani vzrok SAM, ne diagnosticira (73).

\section{Predstavitev \\ kliničnega primera}

Prikazujemo primer otroka, ki je bil sprva voden zaradi SAM, a so kasneje ugotovili, da je vzrok njegovih težav PPB.

Deček je bil rojen kot drugi otrok v družini po normalno potekajoči nosečnosti in porodu, donošen in s primernimi porodnimi merami. V družini ni dednih bolezni ali konsangvinosti. Razvoj je po rojstvu sprva potekal normalno. V drugem letu življenja so pričeli opažati, da se do vrstnikov obnaša neprimerno ter jih poriva in ščipa. Na sistematskem pregledu v starosti treh let je psihologinja opozorila, da bi pri dečku lahko šlo za spektroavtistično motnjo, zato so ga usmerili v ambulanto za avtizem. V sklopu diagnosticiranja avtizma je v starosti 3,5 leta opravil elektroencefalografijo (EEG), ki ni pokazala posebnosti. Izvidi testiranja v obsegu razširjenega presnovnega presejanja novorojenčkov niso pokazali odstopanj. V ospredju je bil slabši govorni razvoj, zato je bil zaradi suma na prevodno okvaro sluha obravnavan tudi pri otorinolaringologu. Pri starosti štirih let so mu zaradi obstrukcijskih hipopnej v spanju opravili tonziloadenoidektomijo in vstavili timpanalno cevko obojestransko. $\mathrm{Na}$ obeh straneh je pričel nositi tudi slušni aparat in obiskovati vrtec v okviru Zavoda za gluhe in naglušne v Ljubljani. Poleg motenj na področju govorno-jezikovnega razvoja in socialnih interakcij so opažali še znižanje kognitivnih sposobnosti, hitro menjavanje razpoloženja in hiperaktivnost. Opisovali so tudi posebnosti na področju senzorne integracije (zavedanje tele-
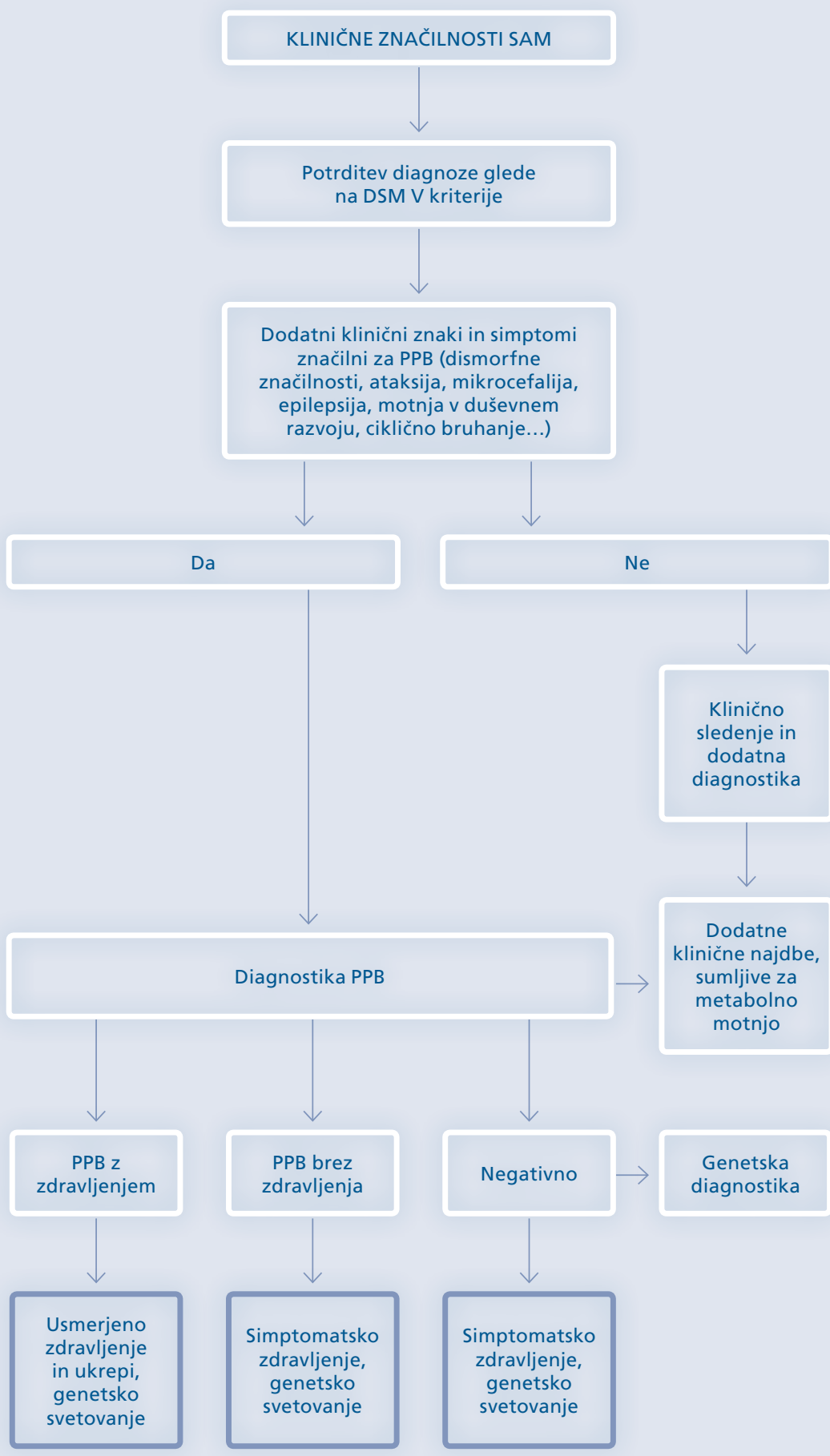

SLIKA 1. PRIMER ALGORITMA ZA OBRAVNAVO OTROK S SPEKTROAVTISTIČNO MOTNJO (PRIREJENO PO (6)).

Legenda: SAM - spektroavtistična motnja, DSM-V - Diagnostični in statistični priročnik za duševne motnje V, PPB prirojena presnovna bolezen

FIGURE 1. A PROPOSED ALGORITHM FOR THE MANAGEMENT OF INBORN ERRORS OF METABOLISM IN CHILDREN WITH AN AUTISM SPECTRUM DISORDER (ADAPTED FROM (6))

Abbreviations: SAM - autism spectrum disorder, DSM-V - The Diagnostic and Statistical Manual of Mental Disorders $\mathrm{V}, \mathrm{PPB}$ - inborn errors of metabolism 
sa, ravnotežje). Redno je obiskoval fizioterapijo in delovno terapijo. Od 4. leta dalje je bil voden $v$ gastroenterološki ambulanti zaradi neopredeljene hepatosplenomegalije in pogostejšega odvajanja redkejšega blata. Izključili so laktozno intoleranco, celiakijo in prehranske alergije. Starši so opazili, da ima manj prebavnih težav, če se drži diete brez laktoze, glutena in fruktoze. Pri starosti 4 leta so opravili molekularno kariotipizacijo, ki ni pokazala odstopanj. Opravil je tudi operativni poseg zaradi popkovne kile. Pričel je hoditi v prvi razred šole s prilagojenim programom. Pri starosti 6 let in 9 mesecev je bil prvič napoten $v$ ambulanto zaradi suma na možno prirojeno presnovno bolezen. Ob kliničnem pregledu smo ugotavljali izrazite obrvi, ki so se stikale $v$ srednji liniji, močne in goste lase $z$ nižjim narastiščem, puhasto poraščenost nad zgornjo ustnico in po telesu ter zmeren zastoj rasti v zadnjih dveh letih. Nevrološko so bile slabše razvite grobe in fine gibalne sposobnosti, po anamnestičnih podatkih pa je progresivno izgubljal nekatere že usvojene aktivnosti, kot sta hoja po stopnicah in tek, očitna pa sta bila tudi zastoj in pomembna regresija govornega razvoja.

Z analizo dokazanih povišanih vrednosti glikozaminoglikanov $v$ urinu so postavili diagnozo mukopolisaharidoza, z dodatnim encimskim diagnosticiranjem pa opredelili tudi znižano aktivnost heparan-N-sulfataze, ki je značilna za MPS tipa IIIA. Bolezen so dodatno potrdili z gensko analizo prisotne bialelne bolezenske spremembe v genu SGSH.

Potek presnovne bolezni kopičenja in diferencialna diagnoza klinične slike sindromskega avtizma

Mukopolisaharidoza tipa IIIA je posledica progresivnega kopičenja nerazgrajenega heparan-sulfata in njegovih fragmentov $v$ celičnih lizosomih zaradi manjkajočega delovanja encima, ki prizadene večino organov v telesu, najbolj pa osrednji živčni sistem. Otrok se rodi brez bolezenskih znakov, s progresivnim kopičenjem pa se pojavlja vse več kliničnih simptomov oz. izgublja že pridobljeno razvojno znanje, kot so higienske navade in jezikovno izražanje. $V$ prvih treh letih so v ospredju zastoj v gibalnem, kognitivnem in predvsem govornem razvoju ter vedenjske težave, ki vodijo v oceno prisotnosti spektroavtistične motnje. V sklopu MPS tipa IIIA kasneje nastopijo tudi izguba sluha, blaga hepatosplenomegalija, hipertrofija tonzil in žrelnice, pogostejše okužbe zgornjih dihal in ušes, grobe poteze obraza in hipertrihoza. K bolezni sodi tudi driska, pojavljajo se dimeljske in popkovne kile. Pri našem otroku je razvoj bolezni potekal nekoliko počasneje, a je razvil večino znakov in simptomov, ki so značilni za mukopolisaharidozo. Za MPS tipa IIIA je značilno, da so zunanji znaki, kot so grobe poteze obraza ali spremembe sklepov, zelo blagi, v ospredju pa so kognitivni upad in moteče vedenjske spremembe, kar lahko vodi v napačno diagnosticiranje kot SAM. Glede na večorgansko prizadetost uvrščamo dečkovo klinično sliko SAM v skupino sindromski avtizem, kar je vedno indikacija za dodatne preiskave v smeri PPB in za razširjeno genetsko diagnosticiranje.

\section{Diagnostične usmeritve pri obravnavi otrok $s$ spektroavtističnimi motnjami}

Smernice za obravnavo otrok s SAM je oblikovala Ameriška akademija za pediatrijo (3). Priporočajo natančno družinsko anamnezo o SAM, klinični pregled otroka s poudarkom na dismorfnih znakih (sindrom fragilnega $X$, Rettov sindrom) in koži (fakomatoze), oceno krivulje rasti, obsega glave in organomegalije, laboratorijske analize za diagnosticiranje PPB in genetske preiskave (molekularna kariotipizacija (delecije in duplikacije DNK)), sekvenciranje naslednje generacije (NGS) in nato po potrebi sekvenciranje eksoma (angl. Whole Exome Seqencing, WES) ali celo genoma (angl. Whole Genome Sequencing, WGS).

Primer algoritma obravnave SAM sloni na že opisani delitvi na sindromski avtizem in nesindromski avtizem, ki jo prikazujemo na Sliki 1 (6).

Biološkega označevalca za SAM še ne poznamo $(1,3)$. $V$ raziskavah so potrdili, da imajo posamezniki s SAM lahko drugačen presnovni profil, kar bi z dodatnimi raziskavami lahko uporabili za razlikovanje med otroki s SAM in zdravimi otroki že pred 5 . letom starosti ter s tem omogočili zgodnejše diagnosticiranje (45). Ena najbolj obetavnih metod za identifikacijo biomarkerjev je neusmerjena metabolomika (angl. untargeted metabolomics) (47). Orodja metabolomike so lahko $v$ pomoč, ko pri osebah s SAM rutinsko presnovno presejanje ne ponudi jasne diagnostične informacije (6). Metabolomika se ukvarja s sistematsko identifikacijo in kvantifikacijo presnovkov v določenem organizmu ali biološkem vzorcu (74). Metabolom je zbirka molekul, ki odraža biokemijsko aktivnost ob točno določenem času v preiskovanem sistemu (47). V zadnjem desetletju je prišlo do tehnološkega napredka (tandemske masne spektroskopije, nuklearne magnetno resonančne spektroskopije), ki je omogočil nadaljnji razvoj metabolomike (47). $Z$ razvojem metabolomike in analitskih podatkovnih baz smo vse bližje odkritju specifičnih biomarkerjev, po katerih bi otroke s SAM v prihodnosti lahko razlikovali od zdravih (47).

$\checkmark$ večini evropskih in ameriških smernic poudarjajo pomembnost genetskega testiranja v diagnosticiranju SAM (14). Zelo pomembno je, da se tega zavedajo strokovnjaki, ki delajo z otroki s SAM (14). Genske variante, ki so povezane s SAM, pokrivajo celoten spekter genskih sprememb - od sprememb v enem baznem paru (angl. single nucleotid variants, SNVs) do izgube ali pridobitve stotine do milijonov baznih parov (angl. copy number variants, CNVs) $(14,75)$. K avtizmu prispevajo tako redke kot pogoste genske varian- 
te, ki se lahko pojavljajo v kodirajočem ali nekodirajočem delu genskega zapisa (7). Ocenjujejo, da so redke genske variante, tako novonastale kot tudi podedovane, vzrok 10-30 \% SAM (76).

Uspešnejša identifikacija genov s tveganjem za razvoj SAM bi lahko vodila $\mathrm{k}$ boljšemu razumevanju patofiziologije avtizma, s čimer bi se ponudile tudi nove možnosti za zdravljenje specifičnih molekularnih mehanizmov SAM in usmerjenega genetskega svetovanja $(8,14)$. Poznavanje genetskega ozadja bi omogočalo tudi opredelitev ocene tveganja za sopojav drugih bolezni osrednjega živčnega sistema in pridruženih somatskih bolezni (14).

\section{Zaključek}

Čeprav so PPB le majhen del diagnostičnih vzrokov sindromske oblike SAM, moramo vsekakor pomisliti tudi nanje. $\mathrm{Na}$ temelju natančnega kliničnega in laboratorijskega diagnosticiranja je potrditev znanih PPB s pridruženo sliko SAM pomembna tako zaradi usmerjenega zdravljenja nekaterih PPB, kot tudi zaradi ciljanega genetskega svetovanja staršem. S prihajajočimi novimi genskimi zdravljenji bo zgodnje diagnosticiranje še toliko bolj pomembno.

\section{Literatura}

1. Macedoni-Lukšič $M$ in delovna skupina. Smernice za celostno obravnavo oseb s spektroavtističnimi motnjami. 1 izd. Ljubljana. Ministrstvo za zdravje, Sektor za zdravstveno varstvo ogroženih skupin prebivalstva; 2009

2. Al-Dewik N, Al-Jurf R, Styles M, Tahtamouni S, Alsharshani D, Alsharshani M, et al. Overview and introduction to autism spectrum disorder (ASD). Adv Neurobiol 2020; 24: 3-42.

3. Hyman SL, Levy SE, Myers SM. Council on children with disabilities, section on developmental and behavioral paediatrics. Identification, evaluation and management of children with autism spectrum disorder. Pediatrics 2020; 145 : e20193447.

4. Moustafa WM, El Foth A. Autism spectrum disorders: the association with inherited metabolic disorders and some trace elements. A retrospective study. CNS Neurol Disord Drug Targets 2019; 18(413): 1-13.
5. Campistol J, Diez-Juan M, Callejon L, De Miguel AF, Casado M, Cazorla AG, et al. Inborn error metabolic screening in individualns with nonsyndromic autism spectrum disorders. Dev Med Child Neurol 2016; 58: 842-47.

6. Gogou M, Evangeliou A. Is metabolic screening necessary in children with autism spectrum disorder? A Mini Review. J Pediatr Neurol 2019; 17(06): 199-205

7. Nakanishi M, Anderson MP, Takumi T. Recent genetic and functial insights in autism spectrum disorder. Curr Opin Neurol 2019; 32: 627-34.

8. Tammimies K. Genetic mechanisms of regression in autism spectrum disorder. Neurosci Biobehav Rev 2019; 102: 208-20.

9. Geschwind DH, State MW. Gene hunting in autism spectrum disorder: On the path to precision medicine. Lancet Neurology 2015; 14(11), 1109-20.

10. Sandin S, Lichtenstein P, Kuja-Halkola R, Hultman C, Larsson $\mathrm{H}$, Reichenberg A. The heritability of autism spectrum disorder. JAMA 2017; 318: 1182-84.

11. Cross-Disorder Group of the Psychiatric Genomics Consortium et al. Genetic relationship between five psychiatric disorders estimated from genome-wide SNPs. Nat Genet 2013; 45 , 984-94.

12. Gaugler T, Klei L, Sanders SJ, Bodea CA, Goldberg $A P$, Lee $A B$, et al. Most genetic risk for autism resides with common variation. Nat Genet 2014; 46: 881-85.

13. Klei L, Sanders SJ, Murtha MT, Hus V, Lowe JK, Willsey AJ, et al. Common genetic variants, acting additively, are a major source of risk for autism. Mol Autism 2012; 3: 9.

14. Vorstman JAS, Parr JR, Moreno-De-Luca D, Anney RJL, Nurnberger JI Jr, Hallmayer JF. Autism genetics: opportunities and challenges for clinical translation. Nat Rev Genet 2017; 18(6): 362-6.

15. Ghaziuddin M, Al-Owain M. Autism spectrum disorders and inborn errors of metabolism: an update. Pediatr Neurol 2013; 49: 232-6. 16. Schiff M, Benoist JF, Aïssaoui S, Boespflug -Tanguy O, Mouren MC, de Baulny $\mathrm{HO}$, et al. Should metabolic diseases be systematically screened in nonsyndromic autism spectrum disorders? PLOS ONE 2011: 6: e21932: 1-4.

17. Maret W. Zinc and human disease. Met lons Life Sci 2013; 13: 389-414.

18. Lulita MF, Caraci F, Cuello AC. A link between nerve growth factor metabolic deregulation and amyloid-B-driven inflammation in Down syndrome. CNS Neurol Disord Drug Targets 2016; 15: $434-47$

19. Faber S, Zinn GM, Kern JC 2nd, Kingston HM. The plasma Zinc/ serum Cu2+ ratio as a biomarker in children with autism spectrum disorders. Biomarkers 2009; 14: 171-80.

20. Lakshmi Priya MD, Geetha A. Levels of trace elements (Cu2+, Zinc, magnesium and selenium) and toxic elements (lead and mercury) in the hair and nail of children with autism. Biol Trace Elem Res 2011; 142: 148-58

21. Russo AJ, Bazin AP, Bigega R, Carlson RS, Cole MG, Contreras DC, et al. Plasma copper and zinc concentration in individuals with autism correlate with selected symptom severity. Nutr
Metab Insights 2012; 5: 41-7.

22. Hoffer A. Children with learning and behavioral disorders. J Orthomol Psychiatry 1976; 5: 228-230.

23. Modabbernia A, Velthorst E, Reichenberg A Environmental risk factors for autism: an evidence-based review of systematic reviews and meta -analyses. Mol Autism 2017; 8: 13.

24. Elsheshtawy E, Tobar S, Sherra K, Atallah S, Elkasaby R. Study of some biomarkers in hair of children with autism. Middle East Current Psychiatry 2011; 18: 6-10.

25. Russo AJ, Devito R. Analysis of copper deficiency induces enhanced depression - like and Zinc plasma concentration and the efficacy of zinc therapy in individual with Asperger's syndrome, pervasive developmental disorder not otherwise specified (PDD- NOS) and autism. Biomark insights 2011; 6: 127-133.

26. Chaidez V, Hansen RL, Hertz-Picciotto I. Gastrointestinal problems in children with autism, developmental delays or typical development. J Autism Dev Disord 2013; 44: 1117-27.

27. Frye RE, Rossignol D, Casanova MF, Brown GL, Martin V, Edelson S et al. A review of traditional and novel treatments for seizures in autism spectrum disorder: findings from a systematic review and expert panel. Front Public Health 2013; 1 : 31.

28. Taurines R, Schwenck C, Westerwald E, Sachse M, Siniatchkin M, Freitag C. ADHD and autism: differential diagnosis or overlapping traits? A selective review. Atten Defic Hyperact Disord 2012; 4: 115-39.

29. Sukhodolsky DG, Bloch MH, Panza KE, Reichow B. Cognitive-behavioral therapy for anxiety in children with high-functioning autism: a meta -analysis. Pediatrics 2013; 132: e1341-50.

30. Angelidou A, Alysandratos KD, Asadi S, Zhang B, Francis K, Vasiadi M, et al. Brief report: "allergic symptoms" in children with autism spectrum disorders. More than meets the eye? J Autism Dev Disord 2011; 41: 1579-85.

31. Tuchman R, Rapin I. Epilepsy in autism. Lancet Neurol 2002; 1: 352-8.

32. Deykin EY, MacMahon B. The incidence of seizures among children with autistic symptoms. Am J Psychiatry 1979; 136: 1310-2.

33. Volkmar FR, Nelson DS. Seizure disorders in autism. J Am Acad Child Adolesc Psychiatry 1990; 29: 127-9.

34. Danielsson S, Gillberg IC, Billstedt E, Gillberg $C$, Olsson I. Epilepsy in young adults with autism: a prospective population-based follow-up study of 120 individuals diagnosed in childhood. Epilepsia 2005; 46: 918-23.

35. Hara H. Autism and epilepsy: a retrospective follow-up study. Brain Dev 2007; 29: 486-90.

36. Rossignol DA, Frye RE. A review of research trends in physiological abnormalities in autism spectrum disorders: immune dysregulation, inflammation, oxidative stress, mitochondrial dysfunction and environmental toxicant exposures. Mol Psychiatry 2012; 17: 389-401.

37. Frye RE, Sequeira JM, Quadros EV, James SJ, Rossignol DA. Cerebral folate receptor autoantibodies in autism spectrum disorder. Mol Psychiatry 2013; 18: 369-81. 
38. Rossignol D, Frye RE. Folate receptor alpha autoimmunity and cerebral folate deficiency in autism spectrum disorders. J Pediatr Biochem 2012; 2: 263-71.

39. Tierney E, Bukelis I, Thompson RE, Ahmed K, Aneja A, Kratz L et al. Abnormalities of cholesterol metabolism in autism spectrum disorders. Am J Med Genet B Neuropsychiatr Genet 2006; 141B: 666-8

40. Novarino G, El-Fishawy P, Kayserili H, Meguid NA, Scott EM, Schroth J et al. Mutations in BCKD-kinase lead to a potentially treatable form of autism with epilepsy. Science 2012; 338: 394-7

41. Mazurek MO, Lu F, Symecko H, Butter E, Bing NM, Hundley RJ, et al. A prospective study of the concordance of DSM-IV and DSM-V diagnostic criteria for autism spectrum disorder. J Autism Dev Disord. 2017; 47(9): 2783-2794.

42. Schopler E, Reichler RJ, DeVellis RF, Daly K. Toward objective classification of childhood autism: Childhood Autism Rating Scale (CARS). J Autism Dev Disord 1980; 10: 91-103.

43. Molloy CA, Murray DS, Akers R, Mitchell T, Manning-Courtney P. Use of the Autism Diagnostic Schedule (ADOS) in a clinical setting. Autism 2011; 15: 143-62.

44. Dawson G, Rogers S, Munson J, Smith M, Winter J, Greenson J, et al. Randomized, controlled trial of an intervention for toddlers with autism: the Early Start Denver Model. Pediatrics 2010; 125: e17-23.

45. Barone R, Alaimo S, Messina M, Pulvirenti A, Bastin J, MIMIC-Autism Group, et al. A Subset of Patients With Autism Spectrum Disorders Show a Distinctive Metabolic Profile by Dried Blood Analyses. Front Psychiatry 2019; 9: 1-11.

46. Glinton KE, Elsea SH. Untargeted metabolomics for autism spectrum disorders: current status and future directions. Front Psychiatry 2019; 10: 1-15.

47. Statista. Prevalence of autism spectrum disorder among children in select countries worldwide as of 2020. Pridobljeno 20.7.2020 s spletne strani: https://www.statista.com/statistics/676354/autism-rate-among-children-select -countries-worldwide/.

48. European Parliament. Subject: Increase in the number of children affected by autism spectrum disorder. Pridobljeno 20.7.2020 s spletne strani: https://www.europarl.europa.eu/ doceo/document/P-9-2020-001299_EN.html.

49. Delobel-Ayoub M, Ehlinger V, Klapouszczak D, Maffre T, Raynaud JP, Delpierre C, Arnaud C. Socioeconomic disparities and prevalence of autism spectrum disorders and intellectual disability. PLoS One 2015; 10: e0141964.

50. Durkin MS, Maenner MJ, Baio J, Christensen D, Daniels J, Fitzgerald R, et al. Autism Spectrum Disorder Among US Children (2002-2010): Socioeconomic, Racial and Ethnic Disparities Am J Public Health 2017; 107: 1818-26.

51. Zhang $Y$, Li N, Li C, Zhang Z, Teng H, Wang $Y$, et al. Genetic evidence of gender difference in autism spectrum disorder supports the female -protective effect. Transl Psychiatry 2020; 10: 4.

52. Barbaresi WJ. The meaning of "regression" in children with autism spectrum disorder: why does it matter? J Dev Behav Pediatr 2016; 37: 506-7.
53. Reiss $A L$, Feinstein $C$, Rosenbaum $K N$. Autism and genetic disorders. Schizophr Bull 1986; 12: 724-38

54. Bilder DA, Kobori JA, Cohen-Pfeffer JL, Johnson EM, Jurecki ER, Grant ML. Neuropsychiatric comorbidities in adults with phenylketonuria: a retrospective cohort study. Mol Genet Metab 2017; 121: 1-8.

55. Schulze A, Hoffmann GF, Bachert P, Kirsch S, Salomons GS, Verhoeven NM, et al. Presymptomatic treatment of neonatal guanidinoacetate methyltransferase deficiency. Neurology 2006; 67: 719-21.

56. Rossignol DA, Frye RE. Mitochondrial dysfunction in autism spectrum disorders: a systematic review and meta-analysis. Molecular Psychiatry 2012, 17: 290-314

57. Van de Kamp JJ, Niermeijer MF, von Figura K, Giesberts MA. Genetic heterogeneity and clinical variability in the Sanfilippo syndrome (types A, B, and C). Clin Genet. 1981; 20: 152-60.

58. Valstar MJ, Ruijter GJG, Van Diggelen OP, Poorthuis BJ, Wijburg F. Sanfilippo syndrome: A mini-review. Journal of Inherited Metabolic Dise ases 2008; 31, 240-52.

59. Fedele AO. Sanfilippo syndrome: causes, consequences, and treatments. Appl Clin Genet 2015; 8: 269-81.

60. Ruijter GJ, Valstar MJ, Van de Kamp JM, van der Helm RM, Durand S, van Diggelen OP, et al. Clinical and genetic spectrum of Sanfilippo type C (MPS IIIC) disease in The Netherlands. Mol Genet Metab. 2008; 93: 104-11.

61. Héron B, Mikaeloff $Y$, Froissart R, Caridade G, Maire I, Caillaud C, et al. Incidence and natural history of mucopolysaccharidosis type III in France and comparison with United Kingdom and Greece. Am J Med Genet A 2011; 155: 58-68.

62. Bax MC, Colville GA. Behaviour in mucopolysaccharide disorders. Arch Dis Child 1995; 73: 77-81.

63. Fraser J, Wraith JE, Delatycki MB. Sleep disturbance in mucopolysaccharidosis type III (Sanfilippo syndrome): a survey of managing clinicians. Clin Genet 2002; 62: 418-21.

64. Valstar MJ, Marchal JP, Grootenhuis M, Colland V, Wijburg FA. Cognitive development in patients with Mucopolysaccharidosis type III (Sanfilippo syndrome). Orphanet J Rare Dis 2011; 6: 43 .

65. Gilkes JA, Heldermon CD. Mucopolysaccharidosis III (Sanfilippo Syndrome) - disease presentation and experimental therapies. Pediatr Endocrinol Rev. 2014; 12( Suppl 1): 133-40. 66. Buhrman D, Thakkar K, Poe M, Escolar ML. Natural history of Sanfilippo syndrome type JmInher Metab Dis 2013; 37(3): 431-437.

67. Shapiro E, King K, Rudser K, Rumsey R, Yund B, Delaney K, Nestrasil I, Whitley C, Potegal $M$. The neurobehavioural phenotype in mucopolysaccharidosis type IIIB: An exploratory study. Molecular Genetics and Metabolism Reports 2016; 6: 41-47

68. Wijburg FA, Wegzryn G, Burton BK, Tylki-Szymanska A. Mucopolysaccharidosis type III (Sanfilippo syndrome) and misdiagnosis of idiopathic developmental disorder, attention deficit/ hyperactivity disorder or autism spectrum disorder. Acta Paediatrica 2013; 102, 462-70.
69. Wolfenden C, Wittkowski A et al. Autism Spectrum Disorder symptomatology in children with Mucopolysaccharide Disease Type III. Br J Learn Disabil 2018; 47: 5-11.

70. Tardieu M, Zérah M, Gougeon ML, Ausseil J, de Bournonville $S$, Husson B et al. Intracerebral gene therapy in children with mucopolysaccharidosis type IIIB syndrome: an uncontrolled phase 1/2 clinical trial. Lancet Neurol 2017; 16: 712-20. 71. Marcó S, Haurigot V, Bosch F. In Vivo Gene Therapy for Mucopolysaccharidosis Type III (Sanfilippo Syndrome): A New Treatment Horizon. Hum Gene Ther 2019; 30: 1211-21.

72. Jira PE, Wevers RA, de Jong J, Rubio-Gozalbo $E$, Janssen-Zijlstra FS, van Heyst AF, et al. Simvastatin. A new therapeutic approach for Smith-Lemli-Opitz syndrome. J Lipid Res 2000; 41: 1339-46.

73. Protokol razširjenega presejanja novorojencev z LC-MS/MS. Dostopno na: https://www. redkebolezni.si/assets1191/wp-content/uploads/2016/05/Redke-bolezni_Protokol-razsirjenega-presejanja-novorojencev-marec-2019. pdf? $\times 85004$.

74. Idle JR, Gonzalez FJ. Metabolomics. Cell Metab 2007; 6: 348-51.

75. De Rubeis S, He X, Goldberg AP, Poultney CS, Samocha K, Cicek AE, et al. Synaptic, transcriptional and chromatin genes disrupted in autism. Nature 2014; 5615; 209-15.

76. Ronemus M, Iossifov I, Levy D, Wigler M. The role of de novo mutations in the genetics of autism spectrum disorders. Nat Rev Genet 2014; $15,133-41$

\section{Anja Krivec Penič}

Zdravstveni dom Koper, Koper, Slovenija

\section{Živa Prijatelj}

Medicinska fakulteta, Univerza v Ljubljani, Ljubljana, Slovenija

\section{Manca Ločičnik}

Splošna bolnišnica Celje, Celje, Slovenija

Doc. dr. Mojca Žerjav Tanšek, dr. med. (kontaktna oseba / contact person)

Klinični oddelek za endokrinologijo, diabetes in presnovne bolezni, Pediatrična klinika, Univerzitetni klinični center Ljubljana, Ljubljana, Slovenija e-naslov: mojca.zerjav-tansek@mf.uni-lj.si

prispelo / received: 13. 10. 2020 sprejeto / accepted: 8. 12. 2020

Krivec Penič A, et. al. Prirojene presnovne bolezni in diagnosticiranje spektroavtističnih motenj. Slov Pediatr 2021; 28(1): 16-23. https://doi. org/10.38031/slovpediatr-2021-1-03. 